\title{
Uterine secretory activity and histology of prepubertal female dogs in an animal model of partial ablation of endometrial glands development ${ }^{1}$
}

\author{
Bianca B. Martins ${ }^{2}$, Natália S. Teixeira ${ }^{3}$, Stéphanie A.M.V. Teixeira ${ }^{4}$, \\ Juliana G. Giannotti ${ }^{5}$, Louisiane C. Nunes ${ }^{5}$, Patricia M.C. Freitas ${ }^{6}$, \\ Mariana Machado-Neves ${ }^{4}$ and Marcelo R. Luz ${ }^{6 *}$ (D)
}

\begin{abstract}
Martins B.B., Teixeira N.S., Teixeira S.A.M.V., Giannotti J.G., Nunes L.C., Freitas P.M.C., Machado-Neves M. \& Luz M.R. 2020. Uterine secretory activity and histology of prepubertal female dogs in an animal model of partial ablation of endometrial glands development. Pesquisa Veterinária Brasileira 40(2):134-140. Setor de Reprodução Animal, Departamento de Clínica e Cirurgia Veterinárias, Escola de Veterinária, Universidade Federal de Minas Gerais, Campus Pampulha, Av. Antonio Carlos 6627, Cx. Postal 567, Belo Horizonte, MG 31270-901, Brazil.E-mail: luzmr@uol.com.br

Inadequate exposure of the female reproductive system to steroids in uterine developmental periods can partially inhibit the development of endometrial glands in dogs. However, the effects of steroids on the formed glands functionality remain unknown, as well as the possible occurrence of endometrial fibrosis. This study aimed to evaluate the secretory activity of endometrial glands in prebubertal female dogs submitted to a protocol of partial ablation of the uterine adenogenesis. Sixteen females of non-specific breed were distributed into two groups; MPA ( $\mathrm{n}=8$ ), females that received applications of medroxyprogesterone acetate every 3 weeks; and C $(n=8)$ untreated control females. Ovariohysterectomy was performed in all animals at the age of 6 months and evaluated the uterine horns by histological and histochemistry exams. The secretion intensity (degrees 1-4) was evaluated using periodic acid-Schiff (PAS) and alcian blue (AB) pH 2.5. Histological evaluation was performed using Masson's trichrome and toluidine blue. Only degree 1 and 2 marks for PAS were observed in both groups, with no difference of uterine secretion intensity between the groups regarding the degrees found. However, the MPA group revealed higher intensity of uterine secretion compared to group $\mathrm{C}(\mathrm{p}<0.05)$. Staining with $\mathrm{AB}$ pH 2.5 also revealed only degree 1 and 2 marks in both groups, with no statistically significance between them. Masson's trichrome staining revealed no marks in the periglandular region in both groups. A higher among of mast cells was observed in the myometrial region of the uterus in both groups. Prepubertal female dogs with partial ablation of the uterine adenogenesis present minimal uterine secretory activity, absence of periglandular fibrosis and increased presence of mast cells in the myometrium compared to endometrium.
\end{abstract}

INDEX TERMS: Uterus, secretion, histology, prepubertal, dogs, partial ablation, endometrial glands, development, medroxiprogesterone acetate, glandular ablation, bitch, morphology.

\footnotetext{
${ }^{1}$ Received on June 13, 2019.

Accepted for publication on July 10, 2019.

${ }^{2}$ Prefeitura de Ibitirama, Rua Anisio Ferreira da Silva 56, Centro, Ibitirama, ES 29540-000, Brazil.

${ }^{3}$ Popvet Centro Veterinário, Av. Gramado 4172, Três Bandeiras, Foz do Iguaçu, PR 85862-240, Brazil.

${ }^{4}$ Laboratório de Biologia Estrutural, Departamento de Biologia Geral, Universidade Federal de Viçosa (UFV), Av. PH Rolfs s/n, Viçosa, MG 36570-900, Brazil.
} 
RESUMO.- [Atividade secretória uterina e histologia de cadelas pré-púberes em um modelo animal de ablação parcial do desenvolvimento das glândulas uterinas.] A exposição inadequada do sistema reprodutor feminino a esteróides em períodos do desenvolvimento uterino pode inibir parcialmente o desenvolvimento das glândulas endometriais em cães. Entretanto, não se conhece os efeitos dos esteróides sobre a funcionalidade das glândulas formadas, bem como a possível ocorrência de fibrose endometrial. Objetivou-se avaliar a atividade secretória das glândulas endometriais de cadelas pré-púberes submetidas a protocolo de ablação parcial da adenogênese uterina. Foram utilizadas 16 fêmeas, sem-raça-definida, distribuídas nos grupos MPA ( $\mathrm{n}=8$ ), fêmeas que receberam aplicações de acetato de medroxiprogesterona a cada 3 semanas, e C $(\mathrm{n}=8)$, fêmeas controle não tratadas. Aos seis meses de idade, foi realizada ovariohisterectomia em todos os animais, e avaliados os cornos uterinos pelo exame histológico e de histoquímica. Para avaliar a intensidade de secreção (graus 1-4), foram utilizadas periodic acid-Schiff e alcian blue (AB) pH 2,5. Para a avaliação histológica foram utilizados tricrômico de Masson e azul de toluidina. Apenas marcações graus 1 e 2 foram observadas para PAS em ambos os grupos, sem diferença na intensidade de secreção uterina entre grupos com relação aos graus encontrados. Entretanto, o grupo MPA apresentou maior intensidade de secreção uterina em relação ao grupo $C(p<0,05)$. Com relação ao $A B$ pH 2,5, em ambos os grupos também foram encontradas apenas marcações de graus 1 e 2, sem diferença estatística entre grupos. Não foram observadas marcações para a coloração de tricrômico de Masson na região periglandular, em ambos os grupos. Foi observada maior quantidade de mastócitos presentes no útero na região do miométrio, em ambos os grupos. Conclui-se que cadelas pré-púberes com ablação parcial da adenogênese uterina apresentam mínima atividade secretória uterina, ausência de fibrose periglandular e maior presença de mastócitos no miométrio em relação ao endométrio.

TERMOS DE INDEXAÇÃO: Útero, secreção, histologia, cadelas, pré-púberes, modelo animal, ablação parcial, desenvolvimento, glândula uterina, acetato de medroxiprogesterona, ablação glandular, cadela, morfologia.

\section{INTRODUCTION}

Endometrial glands are structures present in the uterus of all female mammals. Their function is to synthesize, secret and transport a complex mixture of substances necessary for the embryonic development and maintenance before placentation (Gray et al. 2001). Mucus is a secretion composed mainly of mucin, as well as ions, water and antimicrobial compounds, secreted by several cells and epithelial glands, specialized in maintaining the mucous surface humid (Pluta et al. 2011). It has an important role in the reproductive function and defense of the reproductive system. It undergoes biochemical and physical changes according to the plasma concentration of estrogens and progesterone (Wolf et al. 1978).

Several animal species that received systemic steroids in the first weeks or months of life present reduced reproductive efficiency or even sterility (Gray et al. 2001), which could represent an applicable method to dog population control. Sheep exposed to progestins in the prepubertal period presented ablation of the endometrial glands formation, exhibiting a phenotype called "uterine gland-knockout" (UGKO) (Bartol et al. 1997). In bovines, newborn females treated with implants of progesterone and estradiol benzoate, from birth to puberty, presented with reduced myometrial and endometrial area, in addition to partial ablation of the endometrial glands' development, represented by different degrees of endometrial gland density decrease (Bartol et al. 1995).

In canines, the development of endometrial glands is a post-natal event that usually occurs between birth and the 60th day of life (Cooke et al. 2012). Similarly, to the described for bovines (Bartol et al. 1995), female dogs treated with medroxyprogesterone acetate from birth to six months of age presented with partial ablation of the endometrial glands development (Teixeira et al. 2018). However, there is no description in the literature on the secretory activity of the endometrial glands formed in animals with partial ablation.

This study aimed to evaluate the secretory activity of endometrial glands formed in female dogs submitted to serial applications of medroxyprogesterone acetate from birth to six months of age.

\section{MATERIALS AND METHODS}

Ethics statement. All procedures were performed in accordance with the principles from the Brazilian Colleges of Animal Experiments (COBEA), and at the end of the experiments all animals were donated for adoption.

Animal houses and study design. Sixteen female puppies, with no defined breed, from 5 different litters were used. A total of three or four puppies from each litter were used. Each newborn was randomly assigned to one of two groups on the day of birth: Medroxyprogesterone acetate (MPA) group (Promone-E, Pfizer, Brazil) ( $\mathrm{n}=8)$, which received subcutaneous (SC) application of MPA $(10 \mathrm{mg} / \mathrm{kg})$ in intervals of three weeks, since birth to 6 months of age, for induction of partial ablation of uterine adenogenesis (Teixeira et al. 2018); and Control Group (C) ( $n=8)$, composed by animals that received application of $\mathrm{NaCl} 0.9 \%$ solution, similarly to the MPA group. Animals were kept in collective kennels with access to water and food ad libitum.

Uterine sampling. Samples were collected by ovariohysterectomy from both uterine horns of all female dogs, 6 months after the beginning of experiments. Female dogs were submitted to 12 hours solid fasting and 6 hours liquid fasting before OHS. The anesthetic protocol used included $0.1 \mathrm{mg} / \mathrm{kg} / \mathrm{IM}$ acepromazine (Acepran $0.2 \%$; Vetnil, Brazil), 5.0mg/kg/IV propofol (Propovan; Cristália, Brazil). After induction, animals were kept with inhaled anesthesia using isoflurane (Forane, Baxter, USA).

Histology and histochemistry. Fragments of $0.5 \mathrm{~cm}$ of the uterine horns medial third were fixed in 10\% buffered paraformaldehyde and histologically processed to paraffin inclusion (Luna 1968).

Paraffin blocks containing the fragments were cut in microtome (EDGE $S L-200$ ) to obtain histological sections of $3 \mu \mathrm{m}$ thickness. These were placed in histological slides and stained with different dyes, according to the following description.

Histochemical description was performed using periodic acid-Schiff (PAS) test (Tolosa et al. 2003) to characterize the organ and glands for secretion of neutral polysaccharides (mucins); and alcian blue (AB) pH 2.5 (Bancroft \& Cook 1994), to verify the presence of acidic polysaccharides (mucins).

Histological evaluation of the uterine wall used Masson's trichrome (Luna 1968) to show collagen and muscular fibers; and toluidine blue (Tolosa et al. 2003) to identify metachromatic cells (mast cells).

Histological slides were incubated in periodic acid $0.5 \%$ for 25 minutes and washed with distilled water. They were then kept in cuvette covered with aluminum foil at room temperature, immersed in reactive of Schiff for 15 minutes, and then washed in running water 
for 5 minutes, and in distilled water for 1 minute. Counter-staining was performed with hematoxylin for 30 seconds, followed by a quick wash in running water (Tolosa et al. 2003).

Slides were first washed in 3\% glacial acetic acid solution for 5 minutes and incubated in $1 \% \mathrm{AB}, \mathrm{pH} 2.5$, in $3 \%$ glacial acetic acid solution for 40 minutes at $40^{\circ} \mathrm{C}$. The material was washed in the same buffer solution, and then washed in distilled water. Counter-staining was performed with fast red $0.5 \%$ for 2 minutes and, later, the slides were washed with distilled water (Bancroft \& Cook 1994).

Slides remained submersed in Bouin solution, on $60^{\circ} \mathrm{C}$ oven for one hour, followed by cooling in room temperature. This was followed by washing in running water for 15 minutes and quickly rinsed in distilled water. After this step, the slides were positioned in a staining support and the dyes were applied in the following order: ferrous hematoxylin for 5 minutes, washed in running water for 5 minutes and then distilled water; fuchsin acid with ponceau for 10 minutes, washed in running water for 1 minute and then distilled water; phosphomolybdic acid $5 \%$ for 5 minutes until the cuts were whitening, washed in running water and quickly in distilled water; aniline blue $0.5 \%$ for 5 minutes, washed in running water and quickly in distilled water, acetic acid for 1 minute (Luna 1968).

Histological slides remained 2 minutes in toluidine blue $1 \%$ and were washed in running water (Tolosa et al. 2003).

Three uterine horn cuts were selected for histochemical techniques with PAS and $\mathrm{AB}$ pH 2.5; these were submitted to evaluation in light microscopy to identify the presence or absence of staining by the chemicals determined by each technique, using optical microscope
(Olympus BX 50) with 20x and 40x objectives. When staining was detected, the secretion analysis was evaluated according to the following classification: degree 1 - absence of staining of the secretory cells; degree 2 - slight staining of the secretory cells, or minimal amounts in the lumen; degree 3 - moderate staining of the secretory cells, or moderate amounts in the lumen; degree 4 - intense staining of the secretory cells, or intense amounts in the lumen.

The histological evaluation with Masson's trichrome was performed in light microscopy and identified the presence or absence of staining. The presence of mast cells in the uterus was identified by the characteristic metachromatic staining of the secretory granules, stained by toluidine blue. Endometrium and myometrium were used as the tissue compartments to evaluate the distribution of mast cells. Five fields per histological sample were used to determine the numeric distribution of mast cells $/ \mathrm{mm}^{2}$.

Statistics. The analysis of the intensity of different staining was performed using the non-parametric test of Wilcoxon in independent samples. Data analysis was performed using R (R Development Core Team 2011). Significance level of $p \leq 0.05$ was adopted.

\section{RESULTS AND DISCUSSION}

\section{Glandular fibrosis}

There were no stainings for Masson's trichome in the periglandular region in both groups, which shows that the chronic treatment with MPA did not cause periglandular fibrosis in the female dogs' uterus (Fig.1).

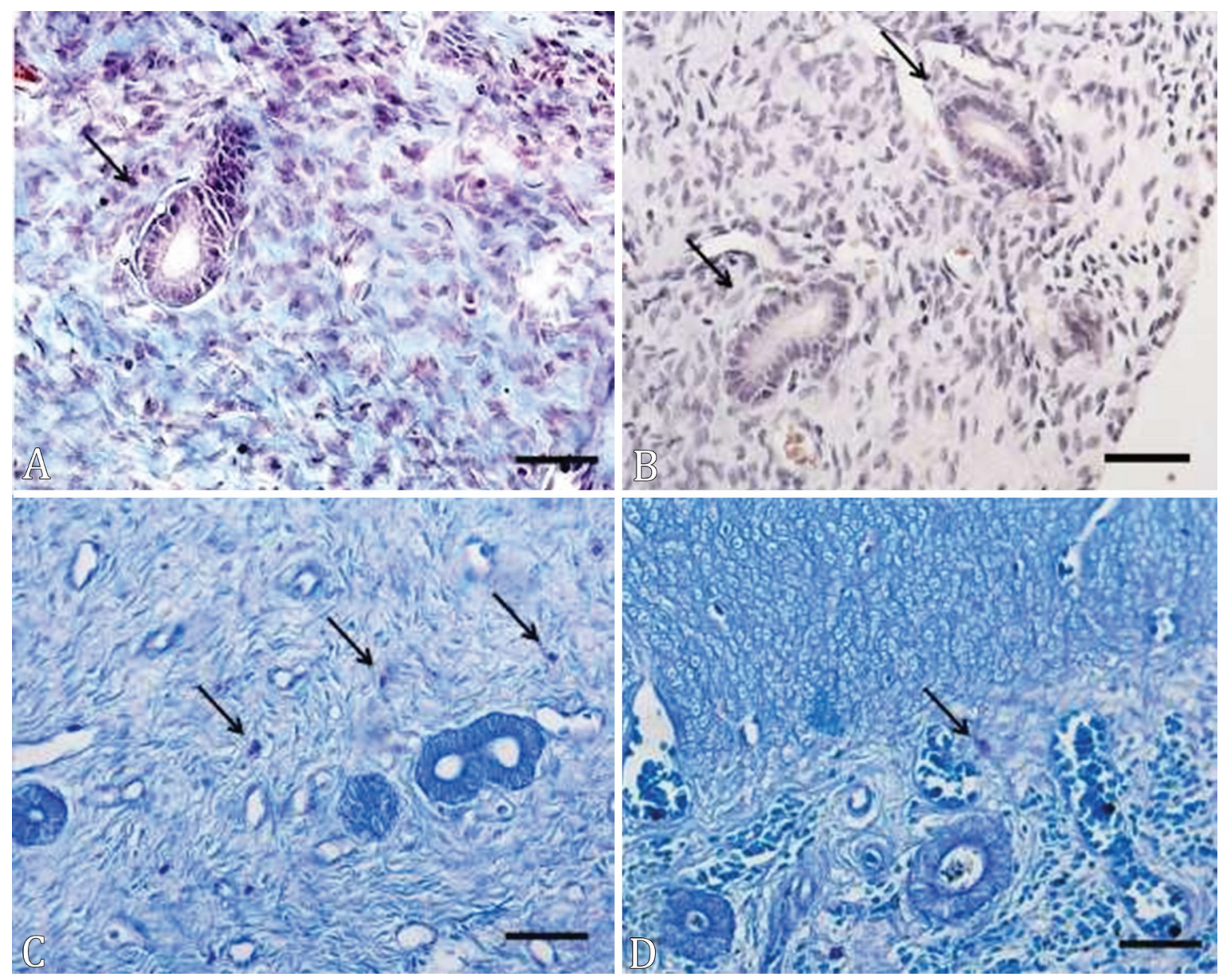

Fig.1. (A-D) Cross-sections of the uterus of prepubertal female dogs treated with medroxyprogesterone acetate, from birth to 6 months of age. (A) Group C, (B) group MPA; mast cells (arrows). MT, bar $=20 \mu \mathrm{m}$. 
Fibrosis is one of the main elements of tissue reaction; therefore, it is important to determine its conformation, localization and composition in order to evaluate how the endometrium is affected. In these lesions, the collagen deposition occurs more commonly around the glands, or associated to the basal membrane (Kenney \& Doig 1986). This alteration compromises the integrity and function of the endometrial glands, which are structures necessary since the pre-implantation period until the complete placental development. Fibrotic glands have irregular epithelium, in addition to changes to the glandular secretion (Walter et al. 2001). High doses of medroxyprogesterone acetate or progesterone or repeated or prolonged exposure in adult female dogs lead to endometrial cystic hyperplasia, with proliferation of endometrial glands and cystic dilation of the same, accumulating fluid in the uterine lumen; fibrosis is a frequent finding (Dow 1959). Thus, the absence of periglandular fibrosis in the present study indicates that the chronic treatment with MPA in prepubertal female dogs possibly do not compromise the fertility of these animals in the adult life regarding the presence or absence of fibrosis. Canine endometrium goes through two phases of development and differentiation; one at the end of anestrous, which is associated with increase of circulating estrogens; and other in the middle of estrous and first week of diestrus, which is associated with estrogens and to luteal progesterone (Galabova et al. 2003). However, according to Van Cruchten et al. (2004), the patterns of endometrial proliferation in cyclical female dogs and its relationship to the concentration of steroid receptors remain unknown. Possibly, this relationship is also unknown in prepubertal female dogs, even though prepubertal female dogs show expression of receptors for progesterone and estradiol in their uterus (Cooke et al. 2012).

\section{Endometrial cystic hiperplasia}

Low vessel density could be subjectively and macroscopically observed in the endometrium of the bitches immediately after ovariohysterectomy. This pattern of vascularization was similar in all experimental bitches. In addition, none of the uterus examined presented any luminal content.

No female dog, in both groups, showed endometrial cystic hyperplasia (ECH) and presence of content in the uterus lumen, regardless of the 6 months long chronic treatment with MPA. These results differ from the found by Dhaliwal et al. (1999), and Kooistra et al. (1997), who verified the occurrence of ECH in adult female dogs treated for 5 or 13 weeks with the same protocol used in the present study. In cyclic adult female dogs, ECH is an abnormal finding; however frequent in the uterus, being more frequent in older dogs, whose uterus was exposed to repeated and chronic progesterone stimuli by the occurrence of several estrous cycles (De Bosschere et al. 2001). The absence of ECH in female dogs in this study is probably due to the immaturity of the dog's reproductive system, as they were still growing and developing, not presenting endometrial glands totally developed and responsive to progestins, although they followed by long-term progesterone treatment with high doses of MPA and at short intervals, and also because at this stage they already have receptor for progesterone and estradiol in the uterus (Cooke et al. 2012). Another possibility is that the absence of endometrial cystic hyperplasia could have been due to the lack of estradiol priming (Dhaliwal et al. 1999), since the animals were prepubertal.

\section{Mast cells}

A higher amount of mast cells in the myometrial region of the uterus was observed in each group compared to the endometrial region (Table 1). However, there was a difference between the groups regarding the amount of mast cells in the myometrium, but not endometrium. In addition, the number of mast cells in the uterus was higher in the animals of the MPA group compared to the C group (Table 1, Fig.1). The mast cells found in the endometrium were observed in the stroma adjacent to the endometrial glands, but they were not present in the epithelium. These were found in the interior of the myometrium, between muscle bundles and around the blood vessels.

Other researchers have reported the presence of mast cells in the uterus of mammals (Brandon \& Evans 1983, Drudy et al. 1991). Similarly, to the observed in this study, studies have observed a smaller amount of mast cells in the endometrium when compared to the myometrium of rats and goats (Karaca et al. 2007, 2009). Moreover, Milne et al. (2001) showed that progestogen treated human myometrium has higher number of mast cells when compared to the endometrium, but the authors did not observe significant different in the amount of mast cells 24 and 48 hours after removing the progestogen.

A study showed that the presence of mast cells in the uterus of female dogs is significantly related to the plasma concentration of progesterone and with the different phases of the estrous cycle (Goericke-Pesch et al. 2010). In addition, some researchers also observed an increased number of mast cells during the progestational phase of the cycle and a reduction due to the action of estrogens (Maraspin \& Bo 1971). In fact, among the known functions of the mast cells present in the uterus, is the high release of histamine during the period of embryonic implantation (Batth \& Parshad 2000). This occurs in a period of the reproductive cycle in which the plasma concentrations are high, justifying the high amount of mast cells observed in the female dog of our study. Even though they were prepubertal dogs, their uterus was impregnated by MPA, which has a long half-life of 24 hours, and strong progestational activity (Romagnoli \& Sontas 2010).

\section{Uterine secretion}

Both groups had only staining of degree 1 (absent) and 2 (slight) for PAS, and there was no difference of intensity of the uterine secretion between the groups at the degree found (Fig.2). However, the MPA group revealed higher intensity of uterine secretion (degree 2$)$ compared to group $\mathrm{C}(\mathrm{p} \leq 0.05)$. Staining with $\mathrm{AB}$ pH 2.5 also revealed only degree 1 and 2 marks in

\begin{tabular}{|c|c|c|c|}
\hline Group & Myometrium & Endometrium & Uterus \\
\hline MPA & $2.5 \mathrm{aA}$ & $0.2 \mathrm{bA}$ & $3.2 \mathrm{~A}$ \\
\hline $\mathrm{C}$ & $1.4 \mathrm{aB}$ & $0.0 \mathrm{bA}$ & $1.6 \mathrm{~B}$ \\
\hline
\end{tabular}

$\mathrm{a}, \mathrm{b}=$ Medians followed by lower case letters distinct in the same row differ between uterus regions by the Wilcoxon test $(\mathrm{p}<0.05), \mathrm{A}, \mathrm{B}=$ medians followed by capital letters distinct in the same column differ between groups by the Wilcoxon test $(\mathrm{p}<0.05)$. 

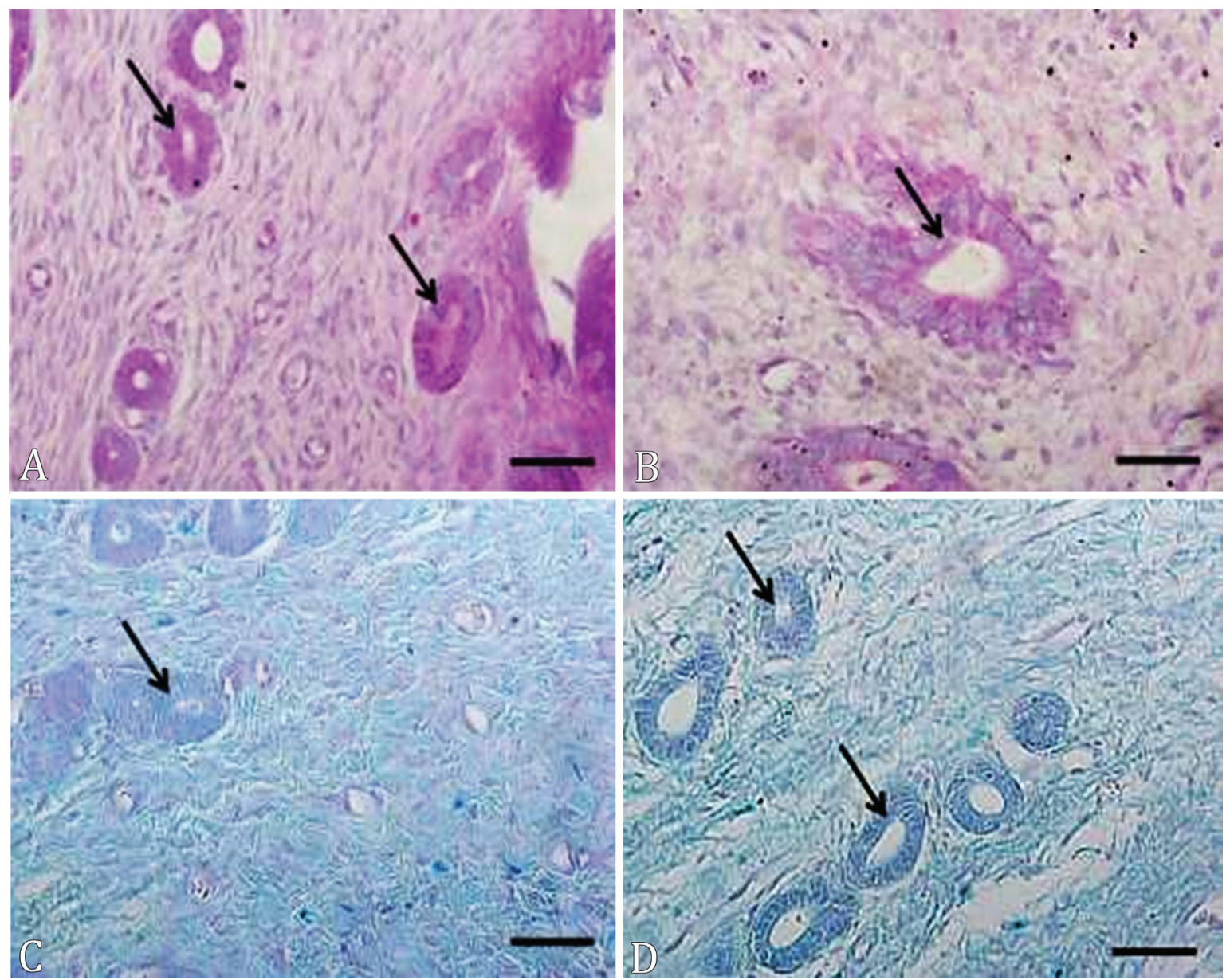

Fig.2. (A-D) Photomicrographs of the cross-sections of the uterus of prepubertal female dogs' treated with medroxyprogesterone acetate, from birth to 6 months of age. (A,C) MPA group, (B,D) group C. Arrows indicate the intensity of secretion in the endometrial glands. (A-B) PAS, bar $=20 \mu \mathrm{m}$. (C-D) $\mathrm{AB} \mathrm{pH} \mathrm{2.5,} \mathrm{bar}=20 \mu \mathrm{m}$.

Table 2. Staining intensity medians (degrees 1 and 2) in the uterus of prepubertal female dogs treated with medroxyprogesterone acetate from birth to six months of age, by PAS and AB pH 2.5 staining

\begin{tabular}{ccccc}
\hline Group & PAS & AB pH 2.5 & Degree 1 \\
\hline MPA & Degree 1 & Degree 2 2 & $0.5 \mathrm{Aa}$ & $1.0 \mathrm{Aa}$ \\
C & $0.0 \mathrm{Aa}$ & $2.0 \mathrm{Ab}$ & $0.0 \mathrm{Aa}$ & $2.0 \mathrm{Aa}$
\end{tabular}

$\overline{a, b}=$ Medians followed by lower case letters distinct in the column differ among themselves by the Wilcoxon test $(\mathrm{p}<0.05), \mathrm{A}, \mathrm{B}=$ medians followed by lower case letters distinct in the column differ among themselves by the Wilcoxon test $(p<0.05)$.

both groups, with no statistically significance between them regarding the uterine secretion ( $\mathrm{p} \leq 0.05$ ) (Table 2, Fig.2).

Physiologically, under the progesterone stimuli, the endometrium undergoes hypertrophy due to the increase in number and size of its glands, which increase the secretory activity, leading to the accumulation of sterile fluid in the uterus lumen. These responses to hormonal actions can be exacerbated with the use of exogenous progestogen (De Bosschere et al. 2001, Pretzer 2008), such as medroxyprogesterone acetate, a progestogen with actions like progesterone. Female dogs from group MPA, after 24 months of treatment, showed higher intensity of uterine secretion (degree 2) by PAS, when compared to group C $(\mathrm{p}<0.05)$; probably due to the response of the progesterone receptors present in the endometrial glands (Cooke et al. 2012). Even after long-term treatment with MPA, progesterone receptors possibly escaped the down-regulation caused by the excess of circulating hormone, as described by De Bosschere et al. (2002a, 2002b) for adult female dogs. On the other hand, the absence of degrees 3 and 4 in the uterine secretion can be justified by the animals' age, prepubertal, and at the beginning of body development. Dogs from both groups were equally stained by $\mathrm{AB} \mathrm{pH} 2.5$.

In contrast, the low intensities of uterine secretion (only degrees 1 and 2) could reflect a picture of subfertility or even sterility in the adult female, in which the total ablation of development of the glands could be explored as an efficient method of population control of dogs. Thus, new protocols for glandular ablation and function impairment should be investigated. 


\section{CONCLUSION}

The long-term exogenous progesterone treatment of prepubertal bitches in a canine model of partial ablation of endometrial glands did not cause periglandular fibrosis or endometrial cystic hyperplasia, increased presence of mast cells in the myometrium compared to endometrium, and also the uterine secretion, even in low degrees. If these findings could reflect alterations in the bitch's fertility remains to be elucidated.

Acknowledgements.- The authors are grateful for the financial support given to the students by "Coordenação de Aperfeiçoamento de Pessoal de Nível Superior" (CAPES), to the "Universidade Federal de Minas Gerais" (UFMG), for the financial support; to the Company "Rações DuMilho" (Bomguy ${ }^{\circledR}$ ) for providing food to the animals involved in the experiment.

Conflict of interest statement.- The authors declare that there is no conflict of interest.

\section{REFERENCES}

Bancroft J.D. \& Cook H.C. 1994. Manual of Histological Techniques and their Diagnostic Application. Churchill Livingstone, Edinburgh. 457p.

Bartol F.F., Johnson L.L., Floyd J.G., Wiley A.A., Spencer T.E., Buxton D.F. \& Coleman D.A. 1995. Neonatal exposure to progesterone and estradiol alters uterine morphology and luminal protein content in adult beef heifers. Theriogenology 43(5):835-844. <http://dx.doi.org/10.1016/0093691X(95)00035-7><PMid:16727674>

Bartol F.F., Wiley A.A., Spencer T.E., Ing N.H., Ott T.L. \& Bazer F.W. 1997. Progestin exposure from birth: epigenetic induction of a unique adult uterine phenotype in sheep: a glandless endometrium. Biol. Reprod. 56(Suppl.1):133.

Batth B.K. \& Parshad R.K. 2000. Mast cell dynamics in the house rat (Rattus rattus) ovary during estrus cycle, pregnancy and lactation. Eur. J. Morphol. 38(1):17-23. <http://dx.doi.org/10.1076/ejom.38.1.0017> <PMid:10550797>

Brandon J.M. \& Evans J.E. 1983. Changes in uterine mast cells during the estrous cycle in the Syrian hamster. Am. J. Anat. 167(2):241-247.<http:// dx.doi.org/10.1002/aja.1001670209><PMid:6351583>

Cooke P.S., Borsdorf D.C., Ekman G.C., Doty K.F., Clark S.G., Dziuk P.J. \& Bartol F.F. 2012. Uterine gland development begins postnatally and is accompanied by estrogen and progesterone receptor expression in the dog. Theriogenology 78(8):1787-1795. <http://dx.doi.org/10.1016/j. theriogenology.2012.05.028><PMid:22959316>

De Bosschere H., Ducatelle R., Tshamala M. \& Coryn M. 2002a. Changes in sex hormone receptors during administration of progesterone to prevent estrus in the bitch. Theriogenology 58(6):1209-1217. <http://dx.doi. org/10.1016/S0093-691X(02)00951-2><PMid:12240923>

De Bosschere H., Ducatelle R., Vermeirsch H., Simoens P. \& Coryn M. 2002b. Estrogen-alpha and progesterone receptor expression in cystic endometrial hyperplasia and pyometra in the bitch. Anim. Reprod. Sci. 70(3/4):251-259. <http://dx.doi.org/10.1016/S0378-4320(02)000131> <PMid:11943494>

De Bosschere H., Ducatelle R., Vermeirsch H., Van Den Broeck W. \& Coryn M. 2001. Cystic endometrial hyperplasia-pyometra complex in the bitch: should the two entities be disconnected. Theriogenology 55(7):1509-1519. <http://dx.doi.org/10.1016/S0093-691X(01)00498-8><PMid:11354710>

Dhaliwal G.K., England G.C.W. \& Noakes D.E. 1999. Oestrogen and progesterone receptors in the uterine wall of bitches with cystic endometrial hyperplasia/ pyometra. Vet. Rec. 145(16):455-457. <http://dx.doi.org/10.1136/ vr.145.16.455><PMid:10576279>
Dow C. 1959. The cystic hyperplasia-pyometra complex in the bitch. J. Comp. Pathol. 69:237-250. <http://dx.doi.org/10.1016/S0368-1742(59)80023$0><$ PMid:13817874>

Drudy L., Sheppard B.L. \& Bonnar J. 1991. The mast cell and histamine concentration of the human post-menopausal uterus. Eur. J. Obstet. Gynecol. Reprod. Biol. 42(1):39-42.<http://dx.doi.org/10.1016/00282243(91)90157-G><PMid:1778289>

Galabova G., Egerbacher M., Aurich J.E., Leitner M. \& Walter I. 2003. Morphological changes of the endometrial epithelium in the bitch during metoestrus and anoestrus. Reprod. Domest. Anim. 38(5):415-420.<http:// dx.doi.org/10.1046/j.1439-0531.2003.00459.X> <PMid:12950696>

Goericke-Pesch S., Schmidt B., Failing K. \& Wehrend A. 2010. Changes in the histomorphology of the canine cervix through the oestrous cycle. Theriogenology 74(6):1075-1081. <http://dx.doi.org/10.1016/j. theriogenology.2010.05.004><PMid:20580071>

Gray C.A., Bartol F.F., Tarleton B.J., Wiley A.A., Johnson G.A., Bazer F.W. \& Spencer T.E. 2001. Developmental biology of uterine glands. Biol. Reprod. 65(5):1311-1323. <http://dx.doi.org/10.1095/biolreprod65.5.1311> <PMid:11673245>

Karaca T., Yoruk M. \& Uslu S. 2007. Distribution and quantitative patterns of mast cells in ovary and uterus of rat. Arch. Med. Vet. 39(2):135-139. <http://dx.doi.org/10.4067/S0301-732X2007000200006>

Karaca T., Yörük M., Uslu S., Cetin Y. \& Uslu B. 2009. Distribution of eosinophil granulocytes and mast cells in the reproductive tract of female goats in the preimplantation phase. Vet. Res. 33(6):545-554. <http://dx.doi. org/10.1007/s11259-009-9203-X><PMid:19184632>

Kenney R.M. \& Doig P.A. 1986. Equine endometrial biopsy, p.723-729. In: Morrow D.A. (Ed.), Current Theraphy in Theriogenology. W.B. Saunders, Philadelphia.

Kooistra H.S., Okkens A.C., Mol J.A., Van Garderen E., Kir-pensteijn J. \& Rijnberk A. 1997. Lack of association of progestin-induced cystic endometrial hyperplasia with GH gene expression in the canine uterus. J. Reprod. Fertil. 51:355-361. <PMid:9404306>

Luna L.G. 1968. Manual of Histologic Staining Methods of Armed Forces Institute of Pathology. Blakinston Division, McGraw-Hill, Washington. 258p.

Maraspin L.E. \& Bo W.J. 1971. Effects of hormones, pregnancy and pseudopregnancy on the mast cell count in the rat uterus. Life Sci. 10(2):111-120. <http://dx.doi.org/10.1016/0024-3205(71)90084-1> <PMid:5575403>

Milne S.A., Rakhyoot A., Drudy T.A., Brechin S., Riley S.C. \& Critchley H.O. 2001. Co-localization of matrix metalloproteinase- 1 and mast cell tryptase in the human uterus. Mol. Hum. Reprod. 7(6):559-565. <http://dx.doi. org/10.1093/molehr/7.6.559><PMid:11385111>

Pluta K., Irwin J.A., Dolphin C., Richardson L., Fitzpatrick E., Gallagher M.E., Reid C.J., Crowe M.A., Roche J.F., Lonergan P., Carrington S.D. \& Evans A.C. 2011. Glycoproteins and glycosidases of the cervix during the periestrous period in cattle. J. Anim. Sci. 89(12):4032-4042.<http:// dx.doi.org/10.2527/jas.2011-4187><PMid:21803974>

Pretzer S.D. 2008. Clinical presentation of canine pyometra and mucometra: a review. Theriogenology 70(3):359-363. <http://dx.doi.org/10.1016/j. theriogenology.2008.04.028> <PMid:18513791>

R Development Core Team 2011. R: A language and environment for statistical computing. R Foundation for Statistical Computing, Vienna. Available at <http://www.R-project.org>

Romagnoli S. \& Sontas H. 2010. Prevention of breeding in the female, p.23-33. In: England G. \& Von Heimendahl A. (Eds), BSAVA Manual of Small Animal Reproduction and Neonatology, 2nd ed. BSAVA, Gloucester.

Teixeira N.S., Martins B.B., Volpato R., Ramos J.L.G., Freitas P.M.C., LauferAmorim R., Lopes M.D. \& Luz M.R. 2018. Partial ablation of endometrial glands in dogs after exposure to progestin during the neonatal period. 
Anim. Reprod. 15(1):45-50. <http://dx.doi.org/10.21451/1984-31432018-0040>

Tolosa E.M.C., Rodrigues C.J., Behmer O.A. \& Freitas Neto A.G. 2003. Manual de Técnicas para Histologia Normal e Patológica. 2 a ed. Manole, Barueri. 331p.

Van Cruchten S., Van Den Broeck W., D’haeseleer M. \& Simoens P. 2004. Proliferation patterns in the canine endometrium during the estrous cycle. Theriogenology 62(3-4):631-641. <http://dx.doi.org/10.1016/j. theriogenology.2003.11.015><PMid:15226018>
Walter I., Klein M., Handler J., Aurich J., Reifinger M. \& Aurich C. 2001. Lectin binding patterns of uterine glands in mares with chronic endometrial degeneration. Am. J. Vet. Res. 62(6):840-845. <http://dx.doi.org/10.2460/ ajvr.2001.62.840 > <PMid:11400838>

Wolf D.P., Blasco L., Khan M.A. \& Litt M. 1978. Human cervical mucus. IV. Viscoelasticity and sperm penetrability during the ovulatory menstrual cycle. Fertil. Steril. 30(2):163-169. <http://dx.doi.org/10.1016/S00150282(16)43454-0> <PMid:680193> 